\title{
Political science in the age of populism: perspectives from Turkey
}

\author{
Duygu Ersoy ${ }^{1} \cdot$ Jülide Karakoç ${ }^{1}$
}

Accepted: 2 November 2020 / Published online: 19 January 2021

(c) European Consortium for Political Research 2021

\begin{abstract}
This article discusses the impact of political transformations on political science in Turkey during the Justice and Development Party (AKP) period from 2002 to the present, with a particular focus on the experiences of political scientists. After first taking power and in accordance with its concerns about attaining domestic and international legitimacy, AKP launched a democratization process by implementing several reforms leading toward EU membership. During this process, the boundaries of politics were broadened, enabling political discussion of certain taboo topics. However, this trend was reversed after AKP's authoritarian populist tendencies strengthened. The party's growing anti-intellectualist stance has also made scholars the target of the government's populist discourse. These circumstances make it critical to examine the challenges Turkey's political scientists experience since their discipline is directly influenced by the boundaries of what is political. This study therefore explores these challenges through ten in-depth interviews conducted with political scientists. It finds that political scientists mostly engage in self-censorship to protect themselves under Turkey's populist authoritarian atmosphere, which has narrowed down in-class discussion and research agendas leading to the impoverishment of the discipline in Turkey.
\end{abstract}

Keywords Academic freedoms $\cdot$ AKP $\cdot$ Authoritarianism $\cdot$ Populism $\cdot$ Selfcensorship

Part of: SI EPS 20th Anniversary

Supplementary information The online version of this article (https://doi.org/10.1057/s41304-02000310-w)

Duygu Ersoy

duygu.ersoy@ altinbas.edu.tr

Jülide Karakoç

julide.karakoc@altinbas.edu.tr

1 Altınbaş University, Buyukdere cad. No: 147, Esentepe Istanbul 34394, Turkey 


\section{Introduction}

Political science in Turkey has always been significantly affected by the political atmosphere in the country, and generally negatively due to the dominance of a security-oriented perspective in domestic and foreign policy. State officials always depict Turkey as a vulnerable state that has faced internal and external enemies since its foundation. While their names have changed over time, there have always been threats perceived or described as a source of "existential insecurity" by the political actors (Akkoyunlu and Öktem 2016: 508).

This approach adopted by Turkish governments has hindered the development of political science as an independent discipline by restricting the boundaries of politics. As the principal agents of their discipline, political scientists have had to omit certain subjects from their research agendas. During the first years of the Justice and Development Party (Adalet ve Kalkınma Partisi, AKP) government, which came to power in 2002 with a democratization agenda, this space seemed to broaden to some extent. However, after the party took an authoritarian turn, this tendency was reversed so that political scientists started to experience serious challenges to their research and teaching. This authoritarian turn of AKP's populism has narrowed the limits of legitimate political discussion with direct consequences for political science in terms of what can be discussed in class and what can be published as a scientific study. This renders analyzing the challenges to political science, which is directly influenced by the boundaries of what is political important. While the experiences of academics in Turkey have been researched in terms of academic freedoms, ${ }^{1}$ no study has examined the challenges that the political transformations created for political science specifically. To fill this gap in the literature, this article examines the impact of AKP's authoritarian turn on political science by focusing on the experiences of political scientists. It argues that the current authoritarian atmosphere has forced political scientists to self-censor in terms of their teaching and research activities, thereby impoverishing political science in Turkey.

In terms of structure, the article proceeds as follows. We first discuss AKP's populism and its move toward authoritarianism. We then evaluate how political scientists have been affected by these developments by discussing the impact of the tightened limits of acceptable topics for political analysis and changes in classroom dynamics.

\section{From relative freedom to authoritarian populism}

Academic freedom in Turkey has always been restricted by a state security-based perspective. These limitations and pressures on academia have been more deeply felt by social scientists, particularly political scientists, during the military coups. In accordance with the way political science in Turkey developed, directed by a

\footnotetext{
1 Please see Bilim Akademisi (2019) and Özdemir Taştan and Ördek (2019) for recent examinations of academic freedoms in Turkey.
} 
concern to train bureaucrats that would constitute the "loyal republican elite" (Erozan and Turan 2004: 359), political scientists are expected to become actors legitimizing the regime and advocating its security-based national interests (Öztürk 2018: 4). In parallel with Turkish politics, academia has also faced many interventions. Following the 1960 military coup, for example, 147 scholars were expelled from their universities. However, upon the reactions by the academia, this decision had been cancelled and with the 1961 Constitution, the concept of autonomy of universities was incorporated in the constitution (Özdemir Taştan and Ördek 2019: 12-13). Following the adoption of the new constitution, democratization attempts encouraged more research on political science (Erozan and Turan 2004: 361).

However, this relatively positive atmosphere was lost due to the constitutional amendments following the 1971 military coup which was based on the pretext of growing student protests and political conflict. Academic freedom was one factor blamed for Turkey's chaotic atmosphere at that time. Many academics were arrested and accused of responsibility for the chaos in universities. This pressure on academia was strengthened further following the 1980 military coup. In 1981, the Council of Higher Education (YÖK, Yüksek Ö $\breve{g r e t i m ~ K u r u m u) ~ w a s ~ e s t a b l i s h e d ~}$ to coordinate and monitor the activities of universities while universities lost their administrative autonomy (Özdemir Taştan and Ördek 2019: 15). Many academics were purged from universities for their ideological stance. Within this framework, social scientists, particularly political scientists, felt more pressure than scholars in other disciplines since the YÖK - as a state-established institution - had extensive authority to control academic activities in universities in accordance with the political limits set by the military regime.

Political intolerance of academics continued into the 1990s, when the Kurdish question and Islamist demands dominated the political sphere. It became "improper" for political scientists to study either issue from any other perspective than that of the state. In particular, political pressure on Islamist activities increased following the so-called post-modern coup on February 28, 1997. This was a declaration by the National Security Council (MGK, Milli Güvenlik Kurulu) against actions of the coalition government led by Necmettin Erbakan from the Welfare Party, which represented the Islamist National Outlook movement. During this period, several scholars were dismissed from their posts at universities - this time "on the suspicion that they were Islamists" (Özdemir Taştan and Ördek 2019: 15).

When AKP was founded in 2001 by a liberal faction led by Recep Tayyip Erdoğan within the National Outlook movement, February 28 was still a recent memory. To avoid the fate of previous Islamists parties, which had been closed down with the accusation of being the center of anti-secular activities, AKP sought domestic and international legitimacy. The founders differentiated themselves from the National Outlook movement by defining their position as "conservative democrat" and the AKP as a "moderately religious" and "neoliberal party" (Dinçşahin 2012: 618-619). To prove that it was an actor within the system, the party searched for coalitions with various social groups in the society (Ersoy and Üstüner 2016), which raised hopes for a more liberal political atmosphere that could directly benefit academia. During the formation and later dissolution of these coalitions, AKP's populism was a dynamic instrument 
for determining the limits of politics, with its inclusionary and exclusionary practices.

It is possible to identify three categories of definitions of populism in the literature: as an ideology, discursive style or political strategy (Bonikowski and Gidron 2013). A major disagreement among these categories is related to the definitions of populism as a "binary" or a "gradational" concept (Moffitt 2016). The gradational definition is not concerned with whether a political actor is populist or not; rather, it focuses on the actor's "degrees of populism", which may change depending on the context (Bonikowski and Gidron 2013: 8-9). Given the changing character of the AKP's populism, this paper is based on a gradational analysis. However, this is not to ignore the merits of other definitions since, despite their differences and ongoing debates between their proponents, they "are not mutually exclusive" (Bonikowski and Gidron 2013: 14). Instead, there are some common themes relevant for all contemporary definitions of populism: in particular, it is considered a political phenomenon centered on the antagonism between homogenous groups of the "corrupted elite" and the "people" (Sözen 2017:16).

Traditionally, the antagonism that right-wing populism establishes between the "elite" and the "people" depends on what is identified by Mardin (1973) as the main cleavage of Turkish society (Aytaç and Elçi 2019: 89). According to this perspective, which AKP follows, Turkish society is characterized by a dichotomy between the center, composing the state elites (military, bureaucracy, intellectuals), and the periphery consisting of "a mixture of traditionalist ethnic, religious, and regional groups that have been systematically kept out of the power-wielding institutions of the state" (Aytaç and Elçi 2019: 90). However, depending on which of its different terms in power we refer to, AKP's presentation of the clash between "the elite" and "the people" varies. For example, its anti-elitist attitude was much more moderate and its definition of "the people" was much more inclusive during its first terms in power, when it was searching for legitimacy within the system as an Islamist party.

This inclusive framework of AKP's populism in its early period was supported by the political reforms that the government implemented to meet the EU's political criteria for Turkey's EU membership. The most significant reform concerned the MGK, which had always been an important institution pressuring governments regarding their decisions on the basis of protecting the state's security and territorial integrity. Under a constitutional amendment in July 2003, the MGK lost its operational authority, restricting its role to making recommendation to governments regarding national security policies (Karakoç 2015:48).

This atmosphere helped broaden the borders of politics and therefore political science since the previously dominant security approach had limited acceptable research areas by drawing the borders of what was political while imposing a restrictive framework regarding academic freedoms. In contrast, the positive atmosphere created by the EU-supported political reforms during the AKP's early period increased academic freedom relatively. Therefore, a good deal of research was conducted on topics such as civil-military relations and the Kurdish question. Previously, for a research to be considered legitimate, generally, it was expected to be analyzed from a security perspective (Esmer et al. 2015: 42, 147, 187, 284). 
However, with its consolidation of power after two terms in office, the AKP radically changed its populist policies when faced with certain challenges. While scholars suggest different starting dates, they agree that AKP took an authoritarian turn. Some suggest that authoritarianism has been rising since 2010 (Özdemir 2020: 2), others suggest the 2011 general elections as the starting date (Akkoyunlu and Öktem 2016: 506), or the Gezi Park protests of mid-2013 (Çelik and Balta 2020: 163). At this point, Öniş states that rather than identifying a single point, it is possible to take these events into account as a series of turning points (2015: 25). The Gezi Protests in mid-2013 which appeared as repercussion of the Arab Uprisings challenging to the AKP rule, the wide-ranging corruption scandal in December 2013 that involved some officials from the government, and the June 2015 elections which resulted in the AKP's loss of majority in the parliament, were all considered existential threats by the AKP rule. Scholars agree that all of these developments led the AKP government to follow a harsh policy against any opposition movement and most of the 2010s was characterized by a severe change in AKP's populism. This was especially the case after the AKP lost its absolute parliamentary majority to form a single party government in 2015, while the party's authoritarian tendencies became much more severe after the attempted coup in 2016. Criminalizing its former allies and forming an alliance with the Nationalist Action Party (Milliyetçi Hareket Partisi, MHP), AKP lost its ability to define "the people" inclusively. During this period, AKP started using a more exclusionary discourse, with AKP officials, particularly President Erdoğan, claiming that there were "internal enemies" linked to and commanded by "external enemies" (Parlak 2015: 512-513). Academia was heavily impacted by this development. Before 2011, as Aytaç and Elçi (2019) argue, the main targets of AKP's discourse of the "corrupt elite" were Turkey's military and judiciary. Following the constitutional referendum in 2010, however, these groups lost their influence over the system, so AKP shifted its populist discourse to target intellectuals and academics in addition to the Republican People's Party (Cumhuriyet Halk Partisi, CHP), journalists, some Western powers, and other actors "that are imagined to plot against Turkey" (Aytaç and Elçi 2019: 99).

The government's harsh reaction against Scholars for Peace (Barış için Akademisyenler, BAK) is a critical example that reveals the rise of anti-intellectualism accompanying AKP's populist authoritarianism. The petition entitled "We will not be a party to this crime!" was signed by hundreds of academics and published in January 2016. The petition called for peace while criticizing the government's policy toward the Kurdish question and accusing it of the "deliberate massacre and deportation" of civilians. The government reacted harshly to the petition. Erdoğan himself attacked the signatories as "those so-called intellectuals" who were committing treason. He also accused them of being the "fifth columns" of external actors threatening Turkey's national security (Weaver 2016). Meanwhile, criminal and administrative investigations were launched against them resulting in a growing number of academics losing their jobs while most were also threatened. Four academics who condemned these violations in a press release were imprisoned with many negative repercussions for academia.

Another example of the government's repression of academics followed the 2016 coup attempt, when the government closed down universities associated with the 
Gülen movement. This movement, which was previously closely tied to AKP and collaborated with the government in intimidating and pressuring dissident academics (Özdemir Taştan and Ördek 2019: 16), was considered the main group responsible for the coup attempt. During this period, over 5,800 academics were fired under emergency decrees issued after July 2016 for alleged links to the Gülen movement (HRW 2018). Even academics who had no affinity or ties with this movement, but were merely working in these closed universities, were stigmatized and made unemployable despite the lack of any clear evidence of wrongdoing. ${ }^{2}$

In conclusion, the BAK process and the coup attempt of 2016 led to a repressive framework characterized by new regulations and academic purges. The intolerance of this framework for any critical perspectives imposed particular challenges for social science scholars (Özkazanç 2017: 10). Turkey’s current political atmosphere, stemming from fluctuations in AKP's populist policies, have significantly impacted the way political science is practiced in Turkey. Before discussing our findings, the following section introduces the method employed in the study.

\section{Method}

The main aim of this study is to examine the challenges that political science faces under rising authoritarian populism in Turkey. Considering the scope of the discipline, which is directly influenced by the boundaries of political discussion set by the governing party, the study focuses on the specific challenges experienced by political scientists. These challenges are researched around two themes: academic freedoms and classroom dynamics.

The analysis is based on 10 semi-structured in-depth interviews conducted with political scientists during September and October 2020. The number of participants was limited given some political scientists' reluctance to participate in the research. This reluctance was related to the overall political atmosphere in Turkey and the sensitive nature of the topic. The political scientists we contacted were uncomfortable with reporting their experiences although we guaranteed confidentiality. With similar concerns, some participants did not agree to be taped so we took notes of the interviews instead. Another difficulty was that the spread of Covid-19 forced us to conduct all interviews online except one, which made our interviewees more cautious while answering questions.

We used snowball sampling to reach our interviewees. These political scientists included 7 women and 3 men, ranging between 38 and 69 years old, with 6 working for private universities and 4 for state universities. Thus, our sample was diverse in terms of age, gender, and institution type. However, despite this diversity, we found consensus in acknowledging the current impoverishment of political science in Turkey.

\footnotetext{
${ }^{2}$ Within this framework, the experience of İştar Gözaydın is a noteworthy example. Please see Öztürk (2018: 2).
} 
Since we investigate how changes in political life in Turkey had influenced the discipline, particularly changes in AKP's populism, we sampled political scientists who taught in the last ten years. Scholars generally agree that AKP's populism became authoritarian in tone during these years. Since this study focuses on the challenges faced by political science in relation to authoritarian populism in Turkey, it was important for the sample to include political scientists who taught during this period enabling them to identify how this political transformation had impacted their way of practicing the discipline. The participants were asked to state this impact in terms of their research agendas, course contents, and relationships with students and university administrators. The following sections present our findings around the discussion of themes of academic freedoms and changing classroom dynamics.

\section{The limits of what is political}

In Turkish political life, there has always been a negative perception of politics and being political because the political has always been viewed as something related to partisanship (Yıldırım 2016: 1-5). Being political is also considered "as an illegitimate reaction to an already existing political system and structure" (Yildirım 2016: 5), thus, harmful to state security. Within this political framework only the activities of government were considered legitimate. Consequently, state officials and government representatives have always actively tried to control and limit the borders of politics and what is political. Particularly, state discourse has excluded specific topics like the Kurdish question and military tutelage from the borders of political discussion (Y1ldırım 2012). Because these subjects were considered a "threat" to state security, scholars researching such topics with a critical perspective were at risk of being viewed as agents illegitimately reacting against Turkey's political system.

A significant actor in preparing the threat list and updating governments was the MGK. Its list, which varied slightly over time, had always been important in shaping the government policies and discourses while various strategies were used to systematically exclude certain political groups and issues from the sphere of the political. During AKP's early periods in power following the reforms en route to EU membership, AKP eliminated the MGK's operational authority and launched the "Kurdish opening". In its "Kurdish opening", the government benefited from the approaches and support of political scientists regarding policy development in these issues (Karakuş and Kahvecioğlu 2013). These developments provided a relatively free political environment and as a result some taboo topics began to be discussed and were included within the political. All our interviewees agree that this was a period of relative freedom.

However, as already indicated, this relatively free environment largely disappeared in the following terms of AKP. As our participants indicated, this policy change has had significant repercussions on the development of political science and experiences of political scientists. First, political scientists had to self-censor to protect themselves whereas a majority of participants said that in AKP's early years in power political scientists could enrich their syllabi with new topics that had been previously coded as threats to state security. Most considered the Gezi Park protests 
and the 15 July coup attempt as turning points for academic freedoms. As most affirmed, political scientists started to revise their syllabi and class discussion topics after these developments. Under these circumstances, some interviewees report that they fear to include the AKP period in their syllabi. One made clear how this selfcensorship happens in practice: "I am lecturing on Turkish politics. However, I prefer not to lecture on the post-2002 period". Another interviewee shares similar concerns by saying, "I feel anxious about the topics included in my syllabus, such as the Kurdish question, the Gezi movement, and LGBT. I also feel uncomfortable while lecturing on political systems and authoritarian regimes." In this regard, another participant puts it, "lecturing on topics like Kurdish issue, Armenian issue were always difficult but previously I could cover these topics at least to some extent. Now, I prefer to skip such topics in my lectures."

Due to such concerns, the majority of interviewees say that they focus more on theoretical aspects of topics to avoid the empirical and practical sides. For example, one participant indicates: "In order to protect myself I avoid discussing case studies involving Turkey." Another participant's statement supports this framework. She indicates that "if I would refer to the Gezi protests, for instance, I lecture about social movements in general and act like I am not talking about the Gezi protests at all."

This self-censorship is also obvious in the selection of class reading lists. According to one of the interviewees, it is no coincidence that Turkish politics lecturers prefer the works of foreign authors in their syllabi, such as Erik-Jan Zürcher, Feroz Ahmad, and Bernard Lewis. This is because they wish to avoid being identified as supporting a certain outlook. This preference also shields them against any accusations of violating the limits of "acceptable" political discussion. This refuge in literature is also evident in another participant's efforts to prevent possible reactions to a critical perspective regarding Turkish politics. As she admits, when the topic includes controversial aspects, she protects herself by saying, "It is not me, it is the literature claiming that."

Turkey's authoritarian environment also affects research thesis topics since some are considered "dangerous" for both students and scholars. As discussed earlier, some participants indicate that while they previously felt relatively free to study supposedly "dangerous topics" in Turkey, they no longer do so. They may even avert students regarding their proposals on these topics. Three of our interviewees noted that they inform their students about the possible consequences of studying these topics in terms of their career paths. As a result of these warnings, they acknowledged that most of the students decided to change their thesis proposals. Beyond their individual experiences, most of the participants emphasize a general concern in academia regarding taboo topics in theses.

Also, scholarly publications have been heavily impacted by the political transformations during the AKP era. The majority of our participants indicate that particularly since the Gezi protests and 15 July coup attempt, they have avoided writing academic articles on "dangerous" topics. Instead, scholars living outside Turkey have published on these topics, apart from a very few scholars in Turkey. Thus, selfcensorship is prevalent in this area too. We infer from our interviews that scholars generally fear being investigated or losing their jobs because of their publications. 
The tendency toward self-censorship has been fueled by the attitudes of colleagues which may be manifested as a form of guardianship. Experiences of two participants are significant in this regard. They acknowledged that their colleagues had advised them not to write about risky topics in Turkish. Another participant's remarks are also striking in this regard, "I was warned by my colleagues about my research agenda on the grounds that studying some topics might be an obstacle for me to get the title of associate professorship. I decided not to study them at all and since then I do not prefer, for instance, to study Turkish foreign policy".

Participation in academic conferences is also influenced by these concerns as the majority of the interviewees hesitate to participate even in international conferences outside of Turkey if their papers cover "dangerous" topics. Besides self-censorship, some participants acknowledge that they are warned by their department to censor their papers: "I submitted two papers to an international conference held outside Turkey. One of my directors warned me in a friendly manner and urged me to withdraw these papers, which were on the 15 July coup attempt." Another participant shares her experience about direct form of censorship: "I was invited to contribute to a book project. After submitting my paper for the project, the editors asked me to remove the parts related to the AKP period from the paper. I had to accept it."

Faced with these limitations, some political scientists declare on the contrary that under these circumstances they have been motivated more to teach about related topics that they think the students should know about. One participant reports that, after the Gezi protests, she wanted to include social movements in her syllabus while, however, leading this discussion in a theoretical manner. Another participant changed her lectures to teach more about concepts like primacy of the law and freedom of expression because she thinks that these concepts should be learnt by political science students more than ever. However, she also acknowledges that she does this using the above-mentioned teaching techniques. As she admits, "any academics who claim that they were not engaging in self-censorship would not be convincing at all."

These forms of self-censorship lead the political scientists to feel uncomfortable and vulnerable. One interviewee indicates that: "The intervention comes from my institution from time to time, but what bothers me most is the self-censorship. When I confront with the fact that I engage in self-censorship I feel very uncomfortable." Another participant also shares similar feelings: "Sometimes I feel very uncomfortable. I ask myself whether we are doing our job in a dishonorable manner." One interviewee summarizes the discomfort that political scientists experience by saying: "Sometimes I wish I had a lab. I would go there and mix some chemicals and write about their reactions without thinking about the implications of my research. I would like to study without being influenced by the political atmosphere and without being worried what I have written". As noted by another participant, this comment reveals how "the realm of politics in Turkey has been narrowed to a great extent, and the ones who have experienced it the most are the political scientists." 


\section{Changing classroom dynamics}

Turkey's societal polarization created and stoked by the government, on the one hand, and investigations against the academics, on the other hand, have also damaged classroom discussions. As important tools within AKP's efforts to reorganize state-citizen relations within a neoliberal framework, new communication centers have been established, such as BIMER ${ }^{3}$ (Communication Center of Prime Ministry) and CIMER (Communication Center of Presidency) (Boyraz 2018: 2). These centers are considered products of "populist institutional design promoted with a discourse of "you govern'". These new communication centers send a message to the people that they are active agents in the government. While these centers are portrayed as tools for the people to participate in governing processes, they have functioned as instruments that enable "monitoring of the voters and their reactions to changing conditions" by impeding "the development of a deliberative public sphere" (Boyraz 2018: 6). This process excludes political discussion about important issues and can only produce temporary solutions (Boyraz 2018: 9).

These communication centers monitoring the peoples' demands and criticisms have also become a government tool to monitor academia. They have turned out to be instruments of a "denouncement" mechanism promoted by the AKP government that impedes discussions on political issues in Turkey. By monitoring discussions in classrooms through these centers, the government indirectly lead academics to censor themselves. Under these circumstances political scientists have become particularly vulnerable because of the scope of the discipline. One of the participants described this monitoring mechanism as "narrowing down the class".

Another interviewee puts it: "Scholars are on constant alert right now. You feel a constant gaze. Fearing the possibility that the students may record you." One of the participant's remarks are noteworthy within this framework: "I witness that professors are stigmatized as 'Gezi supporters' or CHP supporters". Under these circumstances, even if you are not complained by the students, the possibility of this leads you to be more cautious when you are choosing your words during the class."

Students who describe themselves as government supporters may send any discussion in class to the CIMER if they consider it anti-AKP and get upset as acknowledged by most of the participants. This has become a very common way to complain about academics who comment on political issues. Even though sometimes the students have motivations other than the political ones, they still may use this mechanism by making a political complaint. One participant mentions, "to students, complaining their professors based on political reasons is the easiest way. For instance, if they do not like their grades or if you do not provide them the opportunity to have additional exams, they may apply to CIMER on the political ground by benefiting from Turkey's political atmosphere",

The critical point here is that the students, without even informing their university about their complaints, can connect with the state and the presidency specifically

3 BIMER was closed and united with CIMER in 2018. 
through CIMER. One of the participants says that she feels extremely vulnerable under these circumstances that give students so much power. Although only one of the political scientists we interviewed had been complained about to units like CIMER, the classroom performance of most of the interviewees have been influenced by the possibility and awareness of cases in which their colleagues were reported. One participant notes he may have escaped being reported because he works for a private university, mostly attended by upper middle-class students who are not greatly politicized. However, he realizes that he could be the subject of such reports if his circumstances were different, meaning if he had worked for a different university with a more political environment.

At this point, it is important to note that, as one of the participants states, the perceptions and experiences of the scholars who have had ruptures in their careers are different from those who feel more job security. According to one interviewee, their perceptions of the threat from students or the administration depend on this feeling of insecurity. The responses of other interviewees strongly support this point. Scholars who had experienced career ruptures due to political reasons were much more concerned about being reported and accordingly more cautious in their classrooms even if they were now working for a university where they feel relatively free.

Another mechanism that "narrows down" classroom discussion is student evaluations. These evaluations also contribute to the environment of denouncement since, as some participants point out, students increasingly position their professors as supporting a particular political party, which they include in their evaluations. One participant remarked that she had never met such comments until 4-5 years ago. Another participant reports that "students trying to guess my political orientations have asked "what is she doing in this university? She is an anarchist"'. She notes that after these comments she got really scared.

Because students make these comments in relation to classroom discussions, scholars are prevented from talking about Turkish politics freely. As mentioned above, some scholars avoid discussing the AKP period at all or, if they refer to it, they try to soften the discussion and avoid saying anything risky by making it more theoretically focused. Although a few participants in well-established universities declare that they do not feel the need to restrain themselves due to the apolitical character of their students, the majority argue that this is a very important problem that severely affects their position in class. The majority of the interviewees confirm that their in-class discussions are constrained by their fears and concerns following the Gezi protests and the 15 July coup attempt.

The narrowed political space due to these fears and concerns also affects students, as many interviewees acknowledged. Because they are also afraid of being reported, some are unwilling to participate in-class discussions, particularly since the introduction of online education due to Covid-19. One interviewee observes that online class discussions are very poor. When she asks students why, students say they cannot express their opinions since they are recorded. Consequently, the professor admits, "if the debate gets heated, then I dismiss the class and stop recording with the aim of protecting both the students and myself". Another participant shares similar concerns: "A few years ago, there was a very polarized class. Once the debate was heated I tended to end the discussion, because I would like to protect 
myself and the students. In class, there might be students who had ties with the AKP and I was very much concerned about the possibility that my students might be complained by their classmates, which might negatively affect their futures." An incident narrated by a participant reveals how scholars have tangible concerns about the inclass discussions: "During a lecture, the discussion on political issues turned into a fight between students and the lecturer needed the help of the security staff to calm down the students. So, we try to moderate the in-class discussions in a way to prevent any conflict based on polarization."

Here, it may be argued that despite this narrowing of classroom boundaries, students find ways to resist by shifting the political discussion to break times. One participant notes how questions that were normally asked during in-class discussions are now directed to professors at break times. She believes this either reflects students' concerns about being reported or their awareness that professors are uncomfortable sharing their own opinions in class.

Experiences of the interviewed political scientists reveal that narrowed classes have impoverished political science education due to the lack of discussions which may help students to substantiate the analyzed topics. The following remark is very critical in this regard: "After being complained by my students, I became more cautious and decline to discuss controversial issues in class. A student asked me 'how would we learn political science without talking about politics?'”.

\section{Conclusion}

The early years of AKP rule were marked by an atmosphere of relative freedom. AKP's electoral success was promoted both by itself and anti-establishment circles as a victory of the people over the state elite. Despite this dichotomy emphasized within its populist framework, AKP's policies were considered inclusive for various groups representing different positions in the political spectrum. At that time, because AKP wished to gain legitimacy as an Islamist party and be included as an "inner" system actor, it adopted a democratization agenda, including the aim of EU membership. The political reforms realized within this framework widened the scope of politics, allowing political scientists to study political issues that were previously considered taboo.

However, as AKP consolidated its power, this atmosphere of relative freedom changed. The party dissolved its earlier coalitions used to gain legitimacy and revised its definition of the "people" in a more restrictive manner. Moreover, several new challenges encouraged AKP's authoritarian turn and further its exclusionary definition of the "people", particularly the Gezi Protests in mid-2013, the corruption scandal in December 2013, the June 2015 elections, when AKP lost its absolute parliamentary majority, all of which the party considered as existential threats to its rule. Following the 15 July 2016 military coup attempt, AKP's authoritarianism deepened and the government imposed harsh policies against any opposition movement. This authoritarian turn also had consequences for the academia. Various intellectuals and academics became targets of AKP criticism along with the most 
extensive academic purge in the history of the Turkish Republic, with academia now dominated by a security perspective.

Political science was significantly affected by this anti-intellectualist atmosphere and rising authoritarianism. Our in-depth interviews with political scientists provided important insights regarding the challenges political scientists face, although most hesitated to be recorded during the interviews for fear of being investigated or losing their jobs. Unlike the earlier terms of the AKP rule, this hesitation reveals that the government's populist authoritarian stance has led to growing insecurity among scholars. The majority said that they feel constrained, limited, and frustrated by the political atmosphere marked by an authoritarian resilience. Self-censorship has apparently become a common reaction to this security-oriented political sphere. It is noteworthy that the participants mostly did not experience direct interventions from their university administrations or YÖK. Rather, due to rising authoritarian practices supported by various mechanisms, such as BIMER and CIMER, and restricted academic freedoms, they have self-censored their classroom and research activities. Most of the political scientists we interviewed now avoid researching or lecturing about certain themes that they think will upset the ruling party. Similarly, they reorganize their syllabi by removing "dangerous" topics, periods and reading materials. Apart from avoiding any discussion on topics related to the Turkish politics for fear of being reported, they even hesitate to lecture on the central themes of political science, such as separation of powers and political systems, due to their relevance to Turkish politics. It is striking that most of the interviewed political scientists avoid discussing Turkish politics in their classes, which leads a paradoxical condition as clearly shown by a student's reaction received by one of our participants: "How would we learn political science without talking about politics?".

\section{References}

Akkoyunlu, K., and K. Öktem. 2016. Existential insecurity and the making of a weak authoritarian regime in Turkey. Southeast European and Black Sea Studies 16 (4): 505-527.

Aytaç, S.E., and E. Elçi. 2019. Populism in Turkey. In Populism around the World: A Comparative Perspective, ed. Daniel Stockember, 89-108. New York: Springer.

Bilim Akademisi (2019) 'Bilim Akademisi akademik özgürlükler raporu: 2017- 2018', available at https ://bilimakademisi.org/wp-content/uploads/2019/09/2018-19-bilim-akademisi-akademik-ozgurlukraporu-23-eylul-2019.pdf, accessed 25 Sep 2020.

Bonikowski, B., and Gidron, N. 2013. 'Varieties of populism: Literature review and research agenda', Weatherhead Working Paper Series, No. 13-0004.

Boyraz, C. 2018. Neoliberal populism and governmentality in Turkey: The foundation of communication centers during the AKP era. Philosophy and Social Criticism 44 (4): 1-16. https://doi. org/10.1177/0191453718755205.

Dinçşahin, Ş. 2012. A symptomatic analysis of the Justice and Development Party's populism in Turkey, 2007-2010. Government and Opposition 47 (4): 618-640.

Erozan, B. and Turan, İ. (2004) 'The development of political science in Turkey', PS: Political Science and Politics, 37 (2): 359- 363.

Ersoy, D., and F. Üstüner. 2016. 'Liberal intellectuals', narration of the justice and development party in Turkey. Turkish Studies 17 (3): 406-428. https://doi.org/10.1080/14683849.2016.1166057.

Esmer, Y., Ç. Akça, and B.A. Okçuoğlu. 2015. 'Türkiye'de siyaset bilimine yön verenler: Kuram, yöntem ve süreçler. İstanbul: Bahçeşehir Üniversitesi Yayınları. 
Human Rights Watch (2018), 'Turkey: Government Targeting Academics', available at https://www.hrw. org/news/2018/05/14/turkey-government-targeting-academics, accessed 18 November 2020.

Karakoç, J. 2015. Authoritarian tendencies versus democratization: Evidence from Turkey. In Authoritarianism in the Middle East, ed. J. Karakoç, 38-67. Before and After the Arab Uprisings, Basingstoke and New York: Palgrave Macmillan.

Karakuş, A. and Kahvecioğlu, A. (2013) 'İşte Akil İnsanlar Heyeti', Milliyet, available at https://www. milliyet.com.tr/siyaset/iste-akil-insanlar-heyeti-1689038, accessed 1 Sep 2020.

Mardin, Ş. 1973. Center periphery relations: A key to Turkish politics? Daedalus 102 (1): 169-190.

Moffitt, B. 2016. The global rise of populism: performance, political style, and representation. Stanford: Stanford University Press.

Sözen, Y. (2017) 'Demokrasi, Otoriterlik ve Popülizmin Yükselişi', Boğaziçi Üniversitesi-TÜSIAD Dış Politika Forumu Araştırma Raporu, available at https://tusiad.org/tr/yayinlar/raporlar/item/10006 -demokrasi-otoriterlik-ve-populizmin-yukselisi, accessed 15 Sep 2020.

Weaver, M. (2016) 'Turkish prosecutors to investigate academics over Erdoğan petition', The Guardian, 14 January. available at https://www.theguardian.com/world/2016/jan/14/turkish-prosecutors-inves tigate-academics-criticised-erdogan-petition, accessed 2 Sep 2020.

Yıldırım, S. 2016. Arendt Re-defines "the Political" in Turkey: A Theoretical Analysis of the Gezi Protests. Theory in Action 9 (2): 4-20.

Yıldırım, Y. (2012) 'Siyasal Olanı Unutan Siyaset', Birikim, available at https://birikimdergisi.com/gunce 1/611/siyasal-olani-unutan-siyaset, accessed 15 Sep 2020.

Çelik, A.B., and E. Balta. 2020. Explaining the micro dynamics of the populist cleavage in the "new Turkey.' Mediterranean Politics 25 (2): 160-181. https://doi.org/10.1080/13629395.2018.1507338.

Öniş, Z. . 2015. Monopolising the centre: The AKP and the uncertain path of Turkish Democracy. The International Spectator 50 (2): 22-41. https://doi.org/10.1080/03932729.2015.1015335.

Özdemir, Y. 2020. AKP's neoliberal populism and contradictions of new social policies in Turkey. Contemporary Politics 26 (3): 245-267. https://doi.org/10.1080/13569775.2020.1720891.

Özdemir Taştan, İ, and A. Ördek. 2019. OHAL döneminde Türkiye'de akademik özgürlükler araştırması raporu. Ankara: KAGED.

Özkazanç, A. 2017. Trajectory of Turkish higher education in the global context of rising authoritarianism' teaching and learning in democracies under threat: production and transmission of knowledge in changing societies conference; 18-19 September 2017; Central European University, Budapest. Parlak, İ. (2015) 'Yerel Seçimler Ulusal Düşmanlar. Ankara Üniversitesi SBF Dergisi 70 (3): 507-540.

Öztürk, A.E. 2018. Lack of self-confidence of the authoritarian regimes and academic freedom: the case of İşar Gözaydın from Turkey. European Political Science 19: 1-10. https://doi.org/10.1057/s4130 4-018-0170-y.

Publisher's Note Springer Nature remains neutral with regard to jurisdictional claims in published maps and institutional affiliations. 